\title{
An ANAlysis OF SUbJECTUM \\ LITIS AND OBJECTUM LITIS \\ ON DISPUTE ABOUT THE \\ AUTHORITY OF STATE INSTITUTION \\ FROM THE VERDICTS OF THE \\ CONSTITUTIONAL COURT
}

\author{
Anna Triningsih and Nuzul Qur'aini Mardiya \\ The Constitutional Court of the Republic of Indonesia \\ Medan Merdeka Barat Street No.6, Central Jakarta 10110 \\ mkri_annatriningsih@yahoo.com and nuzul_qm@yahoo.com
}

\begin{abstract}
The relationship of mutual control and balance between state institutions gives an opportunity for the emergence of the dispute about the authority of state institutions, especially the dispute about the constitutional authority. In relation to a dispute about authority of state institutions given by the 1945 constitution, a judicial institution is used to resolve the dispute. That judicial institution is the Constitutional Court. The court can evaluate the subjectum litis and objectum litis from the dispute about the authority of state institutions. Therefore that matter will be resolved definitively by the verdict of the Constitutional Court where the verdict is permanent and binding, then later it will become a jurisprudence, and it will be used as a reference. There are eight verdicts of the Constitutional Court related to disputes about the authority of state institutions which are related to the subjectum litis and objectum litis, such as: The verdict of The Consitutional Court No.004/SKLN-IV/2006; the verdict of the Consitutional Court No.030/ SKLN-IV/2006; the verdict of the Consitutional Court No. 26/SKLN-V/2007; the verdict of the Consitutional Court No. 27/SKLN-VI/2008; the verdict of the Consitutional Court No. 1/SKLN-VIII/2010; the verdict of the Consitutional Court No. 2/SKLN-IX/2011; the verdict of the Consitutional Court No. 5/SKLN-IX/2011; and the verdict of the Consitutional Court No. 2/SKLN-X/2012.
\end{abstract}

Keywords: Subjectum Litis, Objectum Litis, Authority Dispute 


\section{INTRODUCTION}

The amandement of the 1945 constitution which has been started since 1999 until 2002 is one of the demands of the reform movement in 1998. The amandement of the 1945 constitution has fundamentally changed the structure of the state administration which implicates the position and the relation between state institutions. To understand the definition, the concept, and the institutionalization, it needs to be based on the new paradigm of the new system of the state administration which has been realized in the 1945 Constitution as the manifestation from the will of the people and the idea of democracy. ${ }^{1}$ The structure of the state administration or the organization of the country is an important aspect in the state of administration. Therefore, a state institution exists both the one written in the 1945 constitution or not written in the 1945 constitution. The state institutions written in the 1945 Constitution has undergone an amandement. ${ }^{2}$

In the concept of separation of powers, the principle of checks and balances between the authorities is considered as the essential and fundamental aspect. Based on the constitutionalism, the principle of separation of powers aims to limit the power of a state so it is expected to avoid the domination of one power over another one, to avoid the subjection and any arbitrary action by the authorities.That principle becomes characteristic of constitutionalism and becomes the main role of the constitution, so the possibility for arbitrariness can be controlled and minimized.

The principle of controlling and balancing each other between state institutions gives an opportunity for the emergence of the dispute between state

\footnotetext{
${ }^{1}$ Arifin Firmansyah, Lembaga Negara Dan Sengketa Kewenangan Antarlembaga Negara (Jakarta: Konsorsium Reformasi Hukum Nasional (KRHN), 2005), 6-16.

2 "The 1945 Constitution of the Republic of Indonesia" (1945). The People's Consultative Assembly (Article 2 and Article 3); President (Article 4, Article 5, Article 7, Article 7A, Article 7B, Article 7C, Article 8, Article 9, Article 10, Article 11, Article 12, Article 13, Article 14, Article 15 dan Article 16); Regional Government (Article 18, Article 18A and Article 18B); The People Representative Council (Article 19, Article 20, Article 20A and Article 21); Regional Representative Council (Article 22C and Article 22D); General Election Commission (Article 22E); Central Bank (Article 23D); Financial Audit Board (Article 23E and Article 23F); Supreme Court (Article 24 and Article 24A); Judicial Commission (Article 24B); Constitutional Court (Article 24 and Article 24C); Indonesian National Armed Forces (Article 20); and Police of the Republic of Indonesia (Article 30). See Abdul Latif, Fungsi Mahkamah Konstitusi dalam Upaya Mewujudkan Negara Hukum Demokrasi (Yogyakarta: Kreasi Total Media, 2007), 196. Compare Abdul Mukthie Fadjar, Hukum Konstitusi Dan Mahkamah Konstitusi (Jakarta: Sekretariat Jenderal dan Kepaniteraan Mahkamah Konstitusi, 2006), 184-91.
} 
institutions, esepecially the dispute about constitutional authority. In a dispute about the state institutions whose authority is given by the 1945 constitution, so there is judicial institution to resolve the dispute. The judicial institution mentioned is the Constitutional Court of the Republic of Indonesia. ${ }^{3}$ The organic provisions in Article $24 \mathrm{C}$ of the 1945 constitution is the Law No. 24 Year 2003 about the Constitutional Court as it has been amanded to the Law No.8 year 2011 about the Amandement on the Law No. 24 Year 2003 about the Constitutional Court. The provision of the Article 10 paragraph (1) and paragraph (2) of the Law No. 24 Year 2003 about the Constitutional Court is the provision of Article ${ }_{24} \mathrm{C}$ paragraph (1) and paragraph (2) of the 1945 constitution.

The authority given by the 1945 constitution is not only a textual authority but also an authority which is implicitly part of the principal authority and an authority which is used to run the principal authority. According to the Constitutional Court, based on the 1945 constitution, a legislator is authorized to establish a state institution and also authorized to give an authority to that institution. If the establishment of a state institution and the authority to give an authority to that institution as it is mentioned in the law is against the 1945 constitution, the Constitutional Court can do a judicial review of a constitution towards the 1945 constitution. Moreover, the establishment of a law can also establish a state institution and give an authority to that institution, although it is not ordered by the 1945 constitution. Therefore, not all authority given by the law has to be understood as an authority which is ordered by the 1945 Constitution.

From the existence of various state institutions in Indonesia, there might be many things happen during the implementation of a state institution with other state institutions, a dispute for instance. Based on the previous explanation, the problem that will be discussed is the analysis of subjectum litis and objectum

\footnotetext{
3 The 1945 Constitution of the Republic of Indonesia. Article $24 \mathrm{C}$ paragraph (1) mentions that "the Constitutional Court has the authority to adjudicateat the first and final instance, the judgement of which is final, to review laws against the Constitution, to judge on authority disputes of state institutions whos authoritues are granted by the Constitution, to judge in the dissolution of a political party, and to judge on disputes regarding the result of a geeral election". While Article 24 C paragraph (2) the 1945 Constitution mentions that the Constitutional Court shall render a judgement on the petition of the People's Representative Council regarded an alleged violation by the President and/or the Vice President according to the Constitution.
} 
litis in resolving a dispute about the authority of state institutions in the Constitutional Court.

\section{DISCUSSION}

In relation to the authority between state institutions, there are many potential disputes that might occur and require attention. The potential disputes are caused by the unclear laws and regulations governing functions, roles, and an authority of an institution which results various interpretation due to the unclear laws and regulations of state institutions. ${ }^{4}$ The implications of check and balances mechanisms in a relation between state institutions on the same level during the implementation of the authority of each state institution might rise a dispute when interpreting the 1945 constitution. If the dispute occurs, an independent organ which is given an authority to resolve that dispute is needed. In a state administration system adopted by the constitution, the mechanism of resolving a dispute about that authority is given to a state insitution called a Constitutional Court. ${ }^{5}$

\subsection{Subjectum Litis}

Article 24 paragraph (1) of the 1945 constitution states that "the Constitutional Court is authorised to conduct a hearing from the first and final level which the verdict is final to '...resolve the dispute about an authority between the state institutions which the authority is given by the constitution...". Then, Article 10 paragraph (1) from the law of the Constitutional Court decides that "the Constitutional Court is authorized to conduct a hearing from the first and final level whose the verdict is final to: examine the law towards the 1945 constitution; resolve a dispute about the authority of state institution whose authority is given by the 1945 Constitution of the State of the Republic of Indonesia; resolve the dissolution of political parties; and resolve the dispute about the result of general eelction".

\footnotetext{
4 Lukman Hakim, "Konsorsium Reformasi Hukum Nasional (KRHN)," Yustisia Jurnal Hukum 80 (2010): 3.

5 Mahkamah Konstitusi Republik Indonesia, "Hukum Acara Mahkamah Konstitusi" (Sekretaris Jenderal dan Kepaniteraan Mahkamah Konstitusi, 2010), 150.
} 
From the above provision, it is known that the authorities of the Constitutional Court is to resolve disputes about authorities of state institutions whose authority is given by the 1945 constitution.The provision is the exit door in resolving a discpute about the authorities of state institutions through the law (due process of law). This authority owned by the Constitutional Court is a principal authorities besides the authority to test constitutionality of a law towards the 1945 Constitution.

Based on the provision in Article 24C paragraph (1) of the 1945 Constitution and Article 10 paragraph (1) of the law of the Constitutional Court, the proposal of a dispute about authority of state institutions can only be filed if the two cumulative requirements have been fulfilled, those are: 1) The petitioner is a state institution mentioned in the 1945 Constitution, and 2) The authority disputed is the authority which is given by the 1945 Constitution. This is in line with the provision of Article 61 paragraph (1) of the law of the Constitutional Court which decides that "The petitioner is the state institution whose authority is given by the 1945 Constitution of the State of the Republic of Indonesia which have direct interest/authority toward the dispute". According to Jimly Asshiddiqqie, in a dispute about the authority of state institutions whose authority is given by the Constitution, there are two requirements has to be fulfilled, those are the constitutional authority decided by the Constitution and the dispute is a result from the differences of interpretation between two or more related state constitutions.

In a concept of positive staatsrecht, a state institution is the state's organ which is usually ruled / become the content of the constitution of a country. ${ }^{6}$ The first requirement is the subjectum litis or having a legal standing to file a petition to the Constitutional Court. Related to subjectum litis, it is required that the state institution needs to be the institution directly mentioned in the

\footnotetext{
${ }^{6}$ See C.F Strong in Modern Political Constitution which states that Constitution is a frame of political society, organized through and by law, one in which law has established permanent institutions which recognized function and definite rights. See also Rosco J. Tresolini and Martin Shapiro in American Constitutional Law which states that there are three things that are regulated in American Constitutional Law, those are the framework or structure of govenment, the power of the government, and it restrains the exercise of these power by governmental officials in order that certain individual right can be preserved. See also Widodo Ekatjahjana and Totok Sudaryanto, Sumber Hukum Tata Negara Formal di Indonesia (Bandung: Citra Aditya Bhakti, 2001), 19-20.
} 
1945 Constitution or the institution which is usually called as constitutional organ. State institutions established by the laws or other laws and regulation are not classified as subjectum litis in a resolve of a dispute about authority of state institutions to the Constitutional Court.

In relation to the second requirement, objectum litis which requires that "the authority of a state institution needs to be the authority given by the 1945 Constitution", it means not all state institutions above can be categorised as petitioners in a resolve of a dispute about the state institutions. Therefore, to be able to become a petitioner in a dispute about a state institution, the two requirements has to be absolutely cumulative. Furthermore, Article 65 of the constitution of the Constitutional Court clearly states that the Supreme Court can not become a respondent in a dispute about the authority of state institutions. Then, Article 2 paragraph (3) PMK 08/2006 also mentions that the Supreme Court can not be the parties, both as a petitioner or as a respondent in a legal procedure on an authority dispute. ${ }^{7}$ On the other hand, outside the legal procedure on an authority dispute, the Supreme Court can involve in a dispute about the authority of a state institution.

If the provision in a law of the Constitutional Court and the Constitutional Court Regulation (Peraturan Mahkamah Konstitusi or PMK) are analyzed, in a formal judicial manner, the Supreme Court cannot become the party if the authority being disputed is related to function and legal procedure (judicial), both as the petitioner or as the respondent in a dispute about the authority of a state institution, but it does not mean that the Supreme Court will not have a dispute with other state institutions, for instances:

1. A dispute about an authority between Judicial Commission and the Supreme Court about the appointment of judges;

2. A dispute about an authority between Judicial Commission and the Supreme Court about supervision and imposition of sanctions for judges.

3. A dispute about an authority between the People Representative Council and the Supreme Court about the apppointment of judges.

7 The Constitutional Court of the Republic of Indonesia, "Constitutional Court Regulation" (n.d.). The Constitutional Court Regulation No. 08/PMK/2006 
Based on requirements about subjectum litis and objectum litis, and based on the Article 2 Paragraph (1) PMK 08/2006, it is decided that the parties who can become petitioners and respondents in a dispute about an authority of state institutions are the People Representatives Council (DPR), the Regional Representatives Council (DPD), The People's Consultative Assembly (MPR), the President, the Audit Board of the Republic of Indonesia (BPK), the local government, and other institutions whose authority is directly given by the 1945 Constitution of the State of the Republic of Indonesia.

The Constitutional Court's verdict has been consistent in determining which state institution can become a petitioner or a respondent in a resolve of a dispute of state institutions whose authority is given by the 1945 constitution. The Constitutional Court always uses two requirements which have been explained before, those are subjectum litis, the respondents or the petititioners are state institutions established based on the 1945 constitution, and objectum litis, the respondents or petitioners are state institutions whose authority is given by the 1945 constitution. Those two requirements are applied by the Constitutional Court absolutely cumulative. So, in a dispute about an authority of state institutions, if the subjectum litis has been fulfilled but the objectum litis is not fulfilled, it means the petition is always "not acceptable/denied".

\subsection{Objectum Litis}

Objectum litis of a dispute about state institutions will limit parties which can become petitioners or respondents during the hearing conducted by the Constitutional Court. The authority of state institutions which can become the object of a dispute is only related to the authority given by the 1945 Consitution to a particular state institution. Therefore, not every state institution, which fulfills the criteria as an organ or state institution running the functions of state and government administration, and having a dispute with other state institutions, can automatically become the party in the dispute. In a dispute about an authority of state institutions, the 
legal standing of the petitioner needs to be based on direct interest in the disputed authority. Therefore the petitioner who files a petition needs to fulfill the following criteria: ${ }^{8}$ The petition is a state institution whose authority is given by the 1945 Constitution; having direct interest in the disputed authority; and relating to causal loss towards one's authority with other institution's authority.

As it has been explained before, both the 1945 Constitution or the law of the Constitutional Court have not explained clearly about the party which is included in the state institution or about the authority directly given by the constitution as it is mentioned in Article $24 \mathrm{C}$ paragraph (1) of the 1945 constitution, this matter gives an authority for the Constitutional Court related to the subjectum litis and the objectum litis of a dispute about state institutions whose authority is given by the law. Therefore, this matter will be decided definitively in the verdict of the Constitutional Court whose verdict is permanent and binding, and later will become a jurisprudence and will be used as reference. ${ }^{9}$

To determine the subjectum litis or the objectum litis of a dispute about a state institution whose authority is given by the 1945 Constitution, the Constitutional Court does grammatische interpretatie (interpeting the grammatical aspect). According to the Constitutional Court, the use of a phrase "a dispute about an authority" before the phrase "state institutions" has an important meaning, since the nature of the Article $24 \mathrm{C}$ paragraph (1) of the 1945 Constitution is indeed "the dispute about an authority" or "what is being disputed", not about "who are in the dispute (parties who are involving in the dispute)". The phrase "state institution" in Article 24C paragraph (1) of the 1945 Constitution needs to be correlated each other and can not be separated with the phrase "whose authority is given by the constitution". By formulating the sub-clause "state institutions whose authority is given

\footnotetext{
${ }^{8}$ Maruarar Siahaan, Hukum Acara Mahkamah Konstitusi Republik Indonesia (Jakarta: Sekretariat Jenderal dan Kepaniteraan Mahkamah Konstitusi, 2006), 194-95.

9 Maruarar Siahaan, "Sengketa Kewenangan Antarlembaga Negara" (pada Diklat Panitera Pengganti Mahkamah Konstitusi, Jakarta, 2008), 13.
} 
by the constitution", implicitly there is a statement "the state institutions whose authority is not given by the constitution ". Therefore, in determining the subjectum litis or the objectum litis of a dispute about the authority of state institutions whose the authority is given by the 1945 Constitution, the authorities given by the Constitution need to be defined/determined first, then determine to what institutions those authorities are given.

In interpreting the authority from the 1945 Constitution, the Constitutional Court states that the Constitutional Court is not only doing the textual interpretation of the provision of the 1945 Constitution which gives authorities to the particular state instituttion, but also there will be possibilities of other implicit authorities which can be found in the primary authorities and other authorities needed (necessary and proper) in order to run those primary authorities which might be included in a law. However, not all authorities given by the law has to be interpreted as authorities which are ordered by the Constitution.

\section{VERDICTS OF THE CONSTITUTIONAL COURT IN RELATION TO THE REQUIREMENTS OF SUBJECTUM LITIS AND OBJECTUM LITIS IN A DISPUTE ABOUT AN AUTHORITY OF STATE INSTITUTION}

The following are explanations about verdicts of the Constitutional Court related to the requirements of subjectum litis and objectum litis in a dispute about authorities of state institutions:

\subsection{The Verdicts of the Constitutional Court No.0o4/SKLN-IV/20o6 in July} 12, 2016, and the Verdict is Denied/Not Accepted (niet ontvankelijk verklaard).

The verdict of the Constitutional Court No. 004/SKLN-IV/2006 is a case filed by Drs. H. M. Saleh Manaf (the Regent of Bekasi) and Drs. Solihin Sari (Vice Regent of Bekasi)...$^{0}$ The petitioner argues his capacity as a state

\footnotetext{
${ }_{10}$ Judicial Review on Dispute over the authority of State Institutions whose authorities are granted by the 1945 Constitution of the State of the Republic of Indonesia, filed by Drs. H. M. Saleh Manaf (the Regent of Bekasi) and Drs. Solihin Sari (Vice Regent of Bekasi) againts the President of the Republic of Indonesia (Respondent I), Ministry of Home Affairs of the Republic of Indonesia (Respondent II), and the Regional People Representatives Council of Bekasi Regency (Respondent III), No. 004/SKLN-IV/2006 (The Constitutional Court of the Republic of Indonesia 2006).
} 
institution to file a petition for dispute about the authority of the state institution as mentioned in Article $24 \mathrm{C}$ of the 1945 Constitution. His capacity as the Regent of Bekasi questions the following points: (i) The authority of the Respondents II in issuing a decree of the Minister of Home Affairs No. 131.32-11 Year 2006 in 4 January 2006 about the Revocation of the Decree of the Ministry of Home Affairs No. 131.32-36 Year 2004 in 8 January 2004 about the ratification of the dismissal and appointment of the Regent of Bekasi, West Java Province, and the authority of the Respondent II in issuing the decree of Ministry of Home Affairs No. 132.32-35 Year 2006 in 19 January 2006 about the the Revocation of the Decree of the Ministry of Home Affairs No. 132.32-37 year 2004 about the Ratification of the Dismissal and Appointment of the Vice Regent of Bekasi, West Java, and (ii) the authority of the Respondent III to issue the Decree of the House of Regional Representatives of Bekasi Regency No. 06/KEP/172.2-DPR/2006 in 28 February 2006 about the approval of the Regional People Representatives Council of Bekasi Regency towards the appointment of the Local Regulation's Draft related to the Revenue and Capital Expenditure of Bekasi Regency in 2006.

The petitioner argues that the Respondent I should correct the action of the Minister of Home Affairs since the minister is the President's aide, and the Respondent II is the responsibility of the President where the President appoints and dismisses the minister as it is mentioned in the Article 17 paragraph (1) and (2) of the 1945 Constitution. In the statement, the Constitutional Court gives interpretation related to the Article $24 \mathrm{C}$ of the 1945 Constitution by defining and explaining the subjectum litis and objectum litis of a dispute about the authority of institutions.

In relation to the case, the Court has formulated "a dispute about the authority of state institutions whose authority is given by the constitution" needs to be understood that the main point of the formula is about the "authority". Therefore, based on the formula, the objectum litis of a dispute about the authority is "the authority about something". In relation to "who holds the authority" or the one who is given the authority will be found 
in the provision of the Constitution. The phrase "state institution" in Article 24C paragraph (1) of the 1945 Constitution needs to be interpreted fully with the phrase "the authority given by the constitution". The use "a dispute about an authority" preceded the phrase "state institutions" has an important meaning, since the nature of Article 24C paragraph (1) of the 1945 Constitution is indeed about the "authority dispute" or about "what is being disputed" and not about "who are involved in the dispute". The meaning will be different if the formulation of Article 24C paragraph (1) of the 1945 Constitution is "......a dispute about state institutions whose authority is given by the constitution". The main point of the last formulation is about the disputed parties/ parties who are involved in a dispute, those are the state institutions, and the object of the dispute is not important anymore.

The phrase "state institution" in Article 24C paragraph (1) of the 1945 constitution has to be related each other and can not be separated with the phrase "whose authority is given by the constitution". By the existent of the formulation "state institutions whose authority is given by the constitution", implicitly the phrase "state institutions whose authority is not given by the constitution" is approved. Therefore, the definition of a state institution has to be understood as general and the phrases "state institutions whose authority is given by the constitution" and "state institutions whose authority is not given by the constitution" can be distinguished. Therefore, the Court argued that a dispute between the Petitioner and the Respondent III is not a dispute about the authority of a state institution whose authority is given by the constitution as it is mentioned by the Article $24 \mathrm{C}$ of the 1945 Constitution.

3.2 The Verdict of the Constitutional Court No. o3o/SKLN-IV/2006 in April 17, and the Verdict is Denied/Not Accepted (niet ontvankelijk verklaard).

The verdict of the Constitutional Court No. 030/SKLN-IV/2006 is a case filed by Indonesian Broadcasting Commission (as a Petitioner). ${ }^{11}$ The

\footnotetext{
${ }_{11}^{11}$ Judicial Review on Dispute over the authority of State Institutions whose authorities are granted by the 1945 Constitution of the State of the Republic of Indonesia, filed by Indonesian Broadcasting Commission (as a Petitioner) against the President of the Republic of Indonesia q.q. the Minister of Communications and Informatics (as the Respondent), No. 030/SKLN-IV/2006 (The Constitutional Court of the Republic of Indonesia 2006).
} 
main petition in the case a quo is a dispute about the authority between the Petitioner against the Respondent about: (i) an authority for granting broadcasting licence, and (ii) an authority of rule-making in terms of broadcasting. The petitioner argued that those two authorities are not textually in the 1945 Constitution. However, those authorities should be interpreted as the beginning of the state's authority to protect the human rights as guaranteed in Article $28 \mathrm{~F}$ of the 1945 Constitution.

The Court, in that Verdict, clearly states the law consideration in defining the subjectum litis and objectum litis from the dispute about the authority of state institutions in the Verdict of the Constitutional Court No. oo4/ SKLN-IV/2006. From the subjectum litis in this petition, the Petitioner is Indonesian Broadcasting Commission and the Respondents are the President q.q. the Minister of Communications and Informatics. Based on the provision in Article 4 paragraph (1), Article 5, and Article 7 of the 1945 Constitution, the President q.q. the Minister of Communications and Informatics are state institutions whose authority are given by the 1945 Constitution. Therefore, the Respondent is the subjectum litis in the case a quo. On the other hand, the 1945 Constitution does not mention and give a constitutional authority to the Indonesian Broadcasting Commission. Thus, the Indonesian Broadcasting Commission is not a state institution as it is meant by the Article $24 \mathrm{C}$ paragraph (1) of the 1945 Constitution, juncto Article 61 paragraph (1) of the Constitutional Court Law.

3.3 The Verdict of the Constitutional Court No. 26/SKLN-V/2007 in March 11, 2008, and the Verdict is Denied/Not Accepted (niet ontvankelijk verklaard).

The verdict of the Constitutional Court No. 26/SKLN-V/2007 is a case filed by the Independent Election Commission of Southeast Aceh Regency level (Petitioner I) and the Regional People Representatives Council (Petitioner II). ${ }^{12}$ The main petition in that case is an authority dispute between the

\footnotetext{
${ }^{12}$ Judicial Review on Dispute over the authority of State Institutions whose authorities are granted by the 1945 Constitution of the State of the Republic of Indonesia, filed by the Independent Election Commission of Southeast Aceh Regency level (Petitioner I) and the Regional People Representatives Council (Petitioner II) against the Independent Election Commission of Nanggroe Aceh Darussalam Province level (Respondent I), the Governor of
} 
Petitioner I against the Respondent I, since the one supposed to issue the Election Results News about the election of the Regent and Vice Regent of Southeast Aceh Regency is the Petitioner I, but it has been taken over by the Respondent I, and the proposal of the appointment of the elected Regent/ Vice Regent to be the Regent/Vice Regent of Southeast Aceh Regency which is supposed to be the authority of the Petitioner II but it has been taken over by the Respondent II. Therefore, the ratification of the appointment of the elected district heads of Southeast Aceh, Ir. Hasanuddin B as the Regent, and M.M. and Drs. H. Syamsul Bahri as the Vice Regent, is not legitimate.

The Court on the verdict a quo clearly states the primary law consideration in defining the subjectum litis and objectum litis from the dipute about the authority of state institutions in the Verdict of the Constitutional Court No. 004/SKLN-IV/2006 and the regulation of the Constitutional Court No. o8/PMK/2006 about the Rules of Procedure in the dispute about Constitutional Authority of State Institutions whose authority is given by the 1945 Constitution. An Independent Election Commission, both Independent Election Commission of Southeast Aceh Regency and Nanggroe Aceh Darussalam (NAD) Province, based on the Law No. 11 Year 2006 junctis Qanun No. 2 Year 2004 as it has been revised to Qanun No. 3 Year 2005 and Qanun No. 7 Tahun 2006, are given an authority by the law to conduct general elections of President/Vice President, members of the People Representatives Council, members of the Regional People Representatives Councils, members of the People Representatives Council of Aceh (DPRA)/ the People Representatives Council of Aceh Regency (DPRK), governor and vice governor, regent and vice regent, and mayor and vice mayor. Thus, it can be decided that the Independent Election Commission of NAD province or Southeast Aceh Regency are not state constitutions meant by the Article 24C paragraph (1) of the 1945 Constitution, Article 61 paragraph (1) of the Law No. 24 Year 2003 about the Constitutional Court (further it is called 
as UUMK), and the Article 2 paragraph (1) about the Regulations of the Constitutional Court No. o8/PMK/2006.

The early formation of the Independent Election Commision of NAD Province and Southeast Aceh Regency are related to the conflict settlement in Aceh Province. Based on TAP MPR No. IV/MPR/1999 and TAP MPR No. IV/MPR/200o, in order to have a conflict settlement, Aceh is decided to be a special autonomous area, which is later confirmed by the Law No. 18 Year 2001 which gives an authority to conduct direct elections of regional heads, which the implementation is given to the Independent Election Commision. Meanwhile, to conduct a national general election, based on the Law No. 12 No.2003, the General Election Commissions (KPU) of province/ regency/city are established. Then in the Law No. 32 Year 2004 about the Local Government, those General Election Commissions are declared as the Regional General Election Commissions (KPUD) whose duty is to conduct a general election of regional heads (Pilkada). To avoid dualism, all of the members of the Regional General Election Commissions of regency/city level become the member of the Independent Election Commission (ex officio). This decision is ruled in Article 226 Paragraph (3) e of the Law No. 32 Year 2004, "the members of Independent Election Commission from the members of the General Election Commissions of the Republic of Indonesia consists of the Head and the Members of the Regional General Election Commissions of Nanggroe Aceh Darussalam Province". This provision is further explained in Qanun No. 2 Year 2004, as it has been amanded with Qanun No.3 Year 2005 and Qanun No. 7 Year 2006. Thus, the Independent Election Commission has its authority from the Law No. 11 Year 2006 about the Government of Aceh, so the Independent Election Commission of province/regency/city levels are not state institutions whose authority is given by the 1945 Constitution and they are also not a national and permanent institutions. Those institutions only exist in NAD Province. Besides, as it is mentioned in Article 265 of Law No. 11 Year 2006, juncto Article 11 Paragraph (7) of Qanun of NAD Province No. 3 Year 2005, the Independent Election Commission, where the 
Law No. 11 Year 2006 were made/established, will end three months after the inauguration of the Regent/Vice Regent.

In relation to the authority of the People Representatives Council of Aceh Regency of Southeast Aceh together with the head of the region as the local government, they are authorized to organize and manage their own government affairs in order to run their autonomy as widely as possible. Thus, the government is authorized to enact the local regulations and other regulations to run the autonomy. In conclusion, the People Representatives Council of Aceh Regency of Southeast Aceh is included as a state institution mentioned as subjectum litis of an authority dispute in front of the Court. To answer the problem, based on the verdict of the Court No. 027/SKLN$\mathrm{IV} / 2006$, both in terms of objectum litis or subjectum litis of the disputed authority filed by the Petitioner II, the Court decides that it is not a dispute about authority of state institutions as it is meant in Article $24 \mathrm{C}$ paragraph (1) of 1945 Constitution, juncto Article 10 paragraph (1) b of the Law of the Constitutional Court.

\subsection{The Verdict of the Constitutional Court No.27/SKLN-VI/2008 February 10, 2009, and the Verdict is Denied/Not Accepted (niet ontvankelijk verklaard).}

The verdict of the Constitutional Court No. $27 / \mathrm{SKLN}-\mathrm{VI} / 2008$ is a case filed by Drs. Aziz Kharie, ME (as the Chairman of the General Election Commissions of North Maluku and as the mandate holder of the General Election Commissions). ${ }^{13}$ The principal issue of $a$ quo is about the authority of the Respondent to appoint the governor and vice governor of North Maluku by using the Presidential Decree No. 85/P Year 2008, which it is considered by the Petitioner as taking over and neglecting the constitutional authority of the Petitioner in appointing the elected candidate pairs of governor and vice governor as follow-up to the results of the General Election of the Regional

\footnotetext{
${ }_{13}$ Judicial Review on Dispute over the authority of State Institutions whose authorities are granted by the 1945 Constitution of the State of the Republic of Indonesia, filed by Drs. Aziz Kharie, ME (as the Chairman of the General Election Commissions of North Maluku and as the mandate holder of the General Election Commissions) against the President of the Republic of Indonesia (as the Respondent)., No. 27/SKLN-VI/2008 (The Constitutional Court of the Republic of Indonesia 2008). Verdict No. 27/SKLN-VI/2008.
} 
Head and the Vice of Regional Head (Pemilukada) of North Maluku Province which is conducted by the Petitioner.

In relation to the subjectum litis of the Petitioner, the Court explains that the provision of 22E paragraph (5) of the 1945 Constitution juncto Article 1 point 4 of the Law 22/2007 shows that the national, permanent, and independent General Election Commissions whose authority is given by the 1945 Constitution to conduct a general election will be called as KPU (Komisi Pemilihan Umum with capital letter for each first letter of the word or Central KPU). On the other hand, the General Election Commissions in province level in casu the General Election Commission of North Maluku Province is not a state constitution whose authority is given by the 1945 Constitution. It is only the organ of the General Election Commissions (the organ of Central KPU) whose authority is given by the Law in casu UU 22/2007, not by the 1945 Constitution. Besides, the General Election of the Regional Head and the Vice of Regional Head (Pemilukada) is not a general election as being mentioned in Article $22 \mathrm{E}$ paragraph (2) of the 1945 Constitution. It is only the realization of the Law in the provision in Article 18 paragraph (4) of the 1945 Constitution.

In relation to the case filed by the Petitioner, the Court evaluates that the letter from the General Election Commission addressed to the General Election Commission of North Maluku is only to let the General Election Commission of North Maluku Province to follow-up the problem of the General Election of the Regional Head and the Vice of Regional Head (Pemilukada) in North Maluku. Therefore, from the point of view of subjectum litis of a case a quo, the Court states that the Petitioner, the General Election Commission of North Maluku, is not a state institution as it is mentioned in the 1945 Constitution and its authority is not given by the 1945 Constitution. On the other hand, the President as the Respondent is indeed a state institution whose authority and position are given by the 1945 Constitution. Therefore, the Petitioner does not fulfill the requirement 
mentioned in Article 24C paragraph (1) of the 1945 Constitution and Article 61 paragraph (1) of the Law of the Constitutional Court.

\subsection{The Verdict of the Constitutional Court No. 1/SKLN-VIII/2010 in March} 11, 2011, and the Verdict is Denied/Not Accepted (niet ontvankelijk verklaard).

The verdict of the Constitutional Court No. 1/SKLN-VIII/2010 is a case filed by Ir.H. Abdullah Tuasikal, M.Si (as the Regent of Central Maluku) and Asis Mahulette, S.H (as the head of the Regional People Representatives Council of Central Maluku Regency). ${ }^{14}$ The principal issue is about the existent of the regulation of the Minister of Home Affairs No. 29 Year 2010 concerning the regional border between West Seram Regency and Central Maluku Province on 13 April 2010 whose consideration is not in line with the Verdict of the Constitutional Court No. 123/PUU-VII/2009 in February 2, 2010, since it still refers to the attachment II of the Law No. 40 year 2003 about the establishment of the East Seram Regency, West Seram Regency, and Aru Island in Maluku Province, whereas the Verdict of the Constitutional Court a quo has changed the norm in Article 7 paragraph (4) of the Law No. 40 Year 2003 about the establishement of the East Seram Regency, West Seram Regency, and Aru Island in Maluku Province and being followed by the explanation and the Attachment II about the border of West Seram Regency as long as it relates to Article 7 paragraph (2) b. This case causes the border of the Petitioner determined by the Minister of Home Affairs becomes unconsistent with the verdict of the Constitutional Court a quo, so it has diminished part of the region owned by the Petitioner, that is Central Maluku Regency. From the legal consideration, the Court explains the meaning of Article $24 \mathrm{C}$ of the 1945 Constitution by defining and explaining the subjectum litis and objectum litis from the dispute about authority of state institutions.

\footnotetext{
${ }_{14}$ Judicial Review on Dispute over the authority of State Institutions whose authorities are granted by the 1945 Constitution of the State of the Republic of Indonesia, filed by Ir.H. Abdullah Tuasikal, M.Si (as the Regent of Central Maluku) and Asis Mahulette, S.H (as the head of the Regional People Representatives Council of Central Maluku Regency) against the Respondent, the Minister of Home Affairs of the Republic of Indonesia., No. 1/ SKLN-VIII/2010 (The Constitutional Court of the Republic of Indonesia 2010).
} 
Based on the Court, from the point of view of subjectum litis, according to Article 18 paragraph (1), paragraph (2), paragraph (3), and paragraph (4) of the 1945 Constitution, and relate to Article 1 Number 2 of the Law 32/2004, the Regent as the head of local goverment in a regency level, together with the Regional People Representatives Council of the Regency, represents the local government, so it is considered as a state institution who owns an authority given by the 1945 Constitution. The authority is to organize and to manage the governmental business based on the autonomous and co-administration task principle of the Petitioner, those are the Regent of Central Maluku and the head of the Regional People Representatives Council of Central Maluku. Those two institutions are state institutions mentioned by the 1945 Constitution and they have authority given by the 1945 Constitution. Therefore, the Petitioner has a legal standing.

Based on the petition, the principal issue related to the petition is about the appointment of area boundaries set by the Minister of Home Affairs based on the regulation of the Minister of Home Affairs No. 29 Year 2010 about the border of the West Seram Regency with Central Maluku province in April 13, 2010. Therefore, the authority owned by the Petitioner is the authoriy which is not given by the 1945 Constitution. The case filed by the Petitioner is the contradiction between the regulation of the Minister of Home Affairs No. 29 Year 2010 about the area boundaries of West Seram and Central Maluku Province against the verdict of the Constitutional Court No. 123/PUU-VII/2009 on 2 February 2010, which has changed the attachment of the Law No. 40 year 2003 about the establishment of East Seram regency, West Seram Regency, and Aru Island Regency in Maluku province, which are part of the Court's authority. In conclusion, since the subjectum litis is correlated to the objectum litis, the petition is not subject or object of the dispute about authority of state institutions. Therefore, based on the Constitutional Court, the petition does not fulfill the provision of Article 61 of the Law of the Constitutional Court juncto Article 2 of the Constitutional Court Regulation No. o8/PMK/2006. 


\subsection{The Verdict of the Constitutional Court No. 2/SKLN-IX/2011 in} September 29, 2011, and the Verdict is Denied/Not Accepted (niet ontvankelijk verklaard).

The verdict of the Constitutional Court No. 2/SKLN-IX/2011 is the case filed by H. Andi Harahap, S.Sos (as the Regent of North Penajam Paser) and Nanang Ali, S.E (as the head of the Regional People Representatives Council of North Penajam Paser Regency). ${ }^{15}$ The principal issue on the dispute about authority of state institutions is related to the decree of the Minister of Environment and Forestry about the determination of Taman Hutan Raya Bukit Soeharto territory, which according to the Petitioner, the Respondent (Minister of Environment and Forestry) does not notice the territorial expansion of Paser Regency which has been expanded into Paser Regency and North Penajam Paser Regency based on the Law No. 7 Year 2002 about the establishment of North Penajam Paser Regency in the North Kalimantan Province.

In relation to the subjectum litis of the Petitioner, the Court explains that based on the Article 18 paragraph (3) and paragraph (4) of the 1945 Constitution, the local government consists of the Regional People Representatives Council and the Local Government (governor, regent, or mayor). It is reaffirmed in Article 3 paragraph (1) b of the Law No. 32 year 2004 about the local government which states "the local government consists of regency/city consisting of local government of regency/city and the Regional People Representatives Council of a regency/city”. Thus, according to the Court, the Petitioner as a regent, and the head of the Regional People Representatives Council of North Penajam Paser Regency are state institutions mentioned by the 1945 Constitution. On the other hand, from the point of view of subjectum litis of the Respondent, the Court explains that based on Article 17 paragraph (3) of the 1945 Constitution states that "Each minister

\footnotetext{
15 Judicial Review on Dispute over the authority of State Institutions whose authorities are granted by the 1945 Constitution of the State of the Republic of Indonesia, filed by H. Andi Harahap, S.Sos (as the Regent of North Penajam Paser) and Nanang Ali, S.E (as the head of the Regional People Representatives Council of North Penajam Paser Regency) against the Minister of Environment and Forestry of the Republic of Indonesia as the Respondent., No. 2/SKLN-IX/2011 (The Constitutional Court of the Republic of Indonesia 2011).
} 
is in charge of a particular responsibility in the government". The Article is further interpreted in Article 5 paragraph (2), Article 4 paragraph (2) b of the Law No.39 Year 2008 about the state of ministry which explains that the forestry is part of the governmental affairs whose the scope is regulated in the 1945 Constitution. Therefore, the Respondent, in casu the Minister of Environment and Forestry, are the unit of the government and part of the state institutions mentioned in the 1945 Constitution who are in charge of the forestry affairs.

In relation to the constitutional authority being disputed by the Petitioner, the Court explains that the constitutional authority of the local government which is regulated in Article 18 of the 1945 Constitution is only a direction and affirmation for the legislator. The aim is to make the autonomy regulation runs as broad as possible, except the affairs which have been regulated by the law and considered as the central governmental affairs. On the other hand, the Law No. 32 Year 2004 has set the governmental affairs which are considered as the central governmental affairs such as foreign political affairs; defense and security affairs; justice affairs; national monetary and fiscal affairs, and religion affairs [vide of Article 10 paragraph (3) of the Law No. 32 Year 2004 about the local government]. However, the central governmental affairs are not only those 7 mentioned matters since the forestry affairs, the Law No. 41 Year 1999 about the Forestry states that the central government is authorized to set the status of a particular territory as part of forest area or not forest area [vide of Article 4 paragraph (2) of the Law No. 41 year 1999 about the forestry affairs]. Since the authority of the central government is based on the Article 33 paragraph (3) of the 1945 Constitution, the Court states that there is not any constitutional authority which is being disputed as it is mentioned in Article 24C paragraph (1) of the 1945 Constitution, Article 10 paragraph (1) b of the Law of the Constitutional Court, Article 3 paragraph (2) of the Constitutional Court Regulation (PMK) 08/2006. 


\subsection{The Verdict of the Constitutional Court No. 5/SKLN-IX/2011 in February}

\section{8, 2012, and the Verdict is Denied/Not Accepted (niet ontvankelijk verklaard).}

The verdict of the Constitutional Court No. 5/SKLN-IX/2011 is a case filed by the Working Committee of Indonesian Advocate (KKAI). ${ }^{16}$ The principal petition related to the issue of letter No. 089/KMA/VI/2010 on 25 June 2010 juncto letter No. 052/KMA/HK.o1/III/2011 on 23 March 2011 where the Respondent is consdered having authority to regulate the organization of advocate, by mentioning PERADI (Indonesian Advocates Association) and KAI (Indonesian Advocate Congress) as if there was already a deal in front of the Respondent that Indonesian Advocates Association is the only one organization of Indonesian advocates by conveying to the head of the Court who can take an oath of the candidate of the advocate who has fulfiled the requirements by following the provision that the oath has to be appointed by the person in charge of the Indonesian Advocate Association, as it is mentioned on the deal on 24 June 2010.

The Petitioner states that the letters issued by the Respondent are considered exceeding the authority given by the 1945 Constitution, since the Indonesian Advocate Association and Indonesian Advocate Congress are indeed not in the Advocate's Law. Therefore, the existent of Indonesian Advocates Association and Indonesian Advocate Congress causes legal uncertainty since it is considered as violating the rights of advocates (in this case: the Working Committee of Indonesian Advocate) to get justice by violating Petitioner's constitutional rights as a state institution. The letter of the Respondent in appointing Indonesian Advocates Association and Indonesian Advocate Congress, by the Petitioner, is considered as an intervension and discrimination by hampering the Petitioner in running the functions of the organization. The requirements of the legal standing that

\footnotetext{
${ }_{16}$ Judicial Review on Dispute over the authority of State Institutions whose authorities are granted by the 1945 Constitution of the State of the Republic of Indonesia, filed by the Working Committee of Indonesian Advocate (KKAI) against the Supreme Court of Indonesia as the Respondent., No. 5/SKLN-IX/2011 (The Constitutional Court of the Republic of Indonesia 2011).
} 
needs to be fulfilled in a dispute about the authority of state institutions whose authority given by the 1945 Constitution are:

a. The Petitioner and Respondent (subjectum litis) are state institutions (obligatory) whose authorities are given by the 1945 Constitution;

b. The authority being diputed (objectum litis) is the authority which is given by the 1945 Constitution (Obligatory).

c. The Petitioner must have direct interest toward the disputed authority which is given by the 1945 Constitution.

Based on the three provisions above, to examine the petition of disputed authority of state institutions whose authority is given by the 1945 Constitution, the Court needs to ensure cumulatively the following points:

I. Is the Petitioner a state institution?

II. Is the authority of the state institution given by the 1945 Constitution?

III. Is the authority disputed by the state institutions?

If one of the cumulative requirements above can not be fulfilled, the Court is not authorized to conduct a hearing. The Court will explains the subjectum litis. The Petitioner is Working Committee of Indonesian Advocate which is not a state institution and is not mentioned in the 1945 Constitution, so the Petitioner is not a state institution. Therefore, based on the Constitutional Court's decision, the petition a quo is not a dispute about authority of state institution meant by the Article 24C Paragraph (1) of the 1945 Constitution, Article 61 paragraph (1) of the Law of the Constitutional Court, Article 3 paragraph (1) of the Constitutional Court Regulation No. o8/PMK/2006 about Rules of Procedure in a dispute about authority of state institutions.

\subsection{The Verdict of the Constitutional Court No. 2/SKLN-X/2012 in July} 31, 2012, and the Verdict is Denied/ Not Accepted (niet ontvankelijk verklaard).

The verdict of the Constitutional Court No. 2/SKLN-X/2012 is a case filed by the President. ${ }^{17}$ The principal issue of the petition by President which is

\footnotetext{
${ }_{17}$ Judicial Review on Dispute over the authority of State Institutions whose authorities are granted by the 1945 Constitution of the State of the Republic of Indonesia, filed by the President against the Respondent, the People Representatives Council and the Audit Board of the Republic of Indonesia., No. 2/SKLN-X/2012 (The Constitutional Court of the Republic of Indonesia 2012).
} 
related to a dispute about an authority of the state institution is about the presence of the People Representatives Council's approval on the President's plan to purchase $7 \%$ shares of PT. Newmont Nusa Tenggara. In the dispute about authority of state institutions involving three institutions, that are the President (Petitioner), the People Representatives Council (Respondent I), and the Audit Board of the Republic of Indonesia (Respondent II), the Constitutional Court states that only the President and the People Representatives Council who have fulfilled the objectum litis required in a dispute about authority of state institutions. ${ }^{18}$ In this case, the Court states that based on Article 4 paragraph (1), Article 23, and Article 23C of the 1945 Constitution, the President's authority is running the government which is correlated with the state's budget. Those are arranging the government's annual program which is arranged in form of State Budget Proposal (RAPBN), then the proposal will be submitted to wait the approval from the People Representatives Council, and managing the state's budget which has been approved by the People Representatives Council. On the other hand, the authorities of the Respondent I are to give approval for the State Budget Proposal submitted by the President and to control the budget management run by the President. However, related to the Respondent II, the Constitutional Court states that it does not fulfill the criteria of objectum litis as it has been fulfilled by the Petitioner and the Respondent I. According to the Court, the Audit Board of the Republic of Indonesia is only examining the budget management. Thus, the disputed authority between the President and the Audit Board of the Republic of Indonesia does not exist. The Audit Board of the Republic of Indonesia can not be considered as the party being disputed in this case. The consideration of the legal standing of this case, the Constitutional Court states:

\footnotetext{
${ }^{18}$ The Consideration of the Constitutional Court, it states that: "According to the Constitutional Court, the object of disputed authority of the case is the authority of the Petitioner to purchase $7 \%$ of the share of PT. Newmont Nusa Tenggara, where it is the derviation authority from the attribution authority mentioned by the 1945 Constitution. Therefore, the disputed authority by the Petititoner a quo is an authority that can be the object of a dispute in a Dispute over the Authority of State Institutions. Since the Respondent I is considered has violated the implementation of the authority, therefore there was an object of disputed authority betweeb tge Petitioner and Respondent I, so it fulfilled the objectum litis in a case a quo. On the other hand, against the Respondent II, according to the Court, since the authority of the Respondent II (Financial Audit Board) is only checking the budget, there is not any disputed authority between the Petitioner and Respondent II. Therefore, the Respondent II cannot be considered as the disputed party in this case".
} 
"the Petitioner has a legal standing to file a petition about the dispute about the authority against the Respondent I, and the dispute about the authority against the Respondent II is not valid". In line with this statement, the expert, Arief Hidayat, states that: "in relation to the Respondent II (the Audit Board of Republic of Indonesia), a dispute about an authority with the government does not exist as long as it is related to the mandate of the law, since the function of the Audit Board of the Republic of Indonesia is to audit (which has been arranged in LHP mandated by the Law), not analysing/interpreting the law used by the institution".

Although the subjectum litis and objectum litis of this case has fulfilled the criteria of a dispute about authority, the Constitutional Court denied the petition. Basically the authority brought to the Constitutional Court is about the authority of the President c.q the Minister of Finance as the State Treasurer through Government Investment Center (PIP). The President is authorized to do divestment of $7 \%$ of shares to PT. NNT without asking the approval of the People Representatives Council. According to the President, the reason is due to the government's power, which the state budget management is part of it, and it is the domain of the executive. On the other hand, a different point of view from the President, the People Representative Council states its objection that before the President does the divestment of $7 \%$ of shares to PT. NNT which is represented by the Minister of Finance as the State Treasurer through the Government Investment Center (PIP), the President needs to submit an approval first to the People Representative Council as the representative of people of Indonesia.

The Constitutional Court considers three points, the first is the Government Investment Center is the Public Service Agency (BLU) according to the law. The Public Service Agency is established to improve services to the public in order to advance the public welfare and to educate the nation. The wealth of Public Service Agency is the wealth of the country which can not be separated as the wealth of the State Owned Enterprises (BUMN). The second, the Government Investment Center is a hierarchical organ under the Minister of Finance. Due to its position, the state budget plan and the budget of the Government Investment Center are consolidated into 
the budget plan of the Ministry of Finance which based on the Article 15 paragraph (5) of the Law of the State's Finance, the State Budget approved by the People Representatives Council covers the unit of the organization, function, program, activities and the type of budget. Thus, all the investment programs of the Government Investment Center have to be included in the budget plan and later will be included in the State Budget Proposal (RAPBN), then it is approved by the People Representatives Council. The approval of the People Representatives Council becomes very important so the President's order c.q The Minister of Financial is not arbitrary or does not exceeds the limit in spending the investment funds or the accumulation of the revenue of the Government Investment Center, since the Government Investment Centeris is not a state enterprises which can be separated. The third, in a state administration in Indonesia, especially the relation between the President and the People Representatives Council, related to the Government Investment Center, the allocation of the investment fund of the Government Investment Center is clearly mentioned in the State Budget or it has been discussed and approved during the discussion of the State Budget Proposal (RAPBN). In a case where the President wants to spend the fund from the Government Investment Center which has not been approved by the People Representatives Council, if it is not for the infrastructure, the President needs to ask for approval from the People Representatives Council, for instance to repurchase (buy back) the State Owned Enterprises' shares which has gone public through the Government Investment Center on 14 October 2008. In this case, the Minister of Finance, as the State Treasurer, cannot automatically do the investment by using the fund from the Government Investment Center and/or the accumulation of the revenue of the Government Investment Center, except if the fund will be used for the infrastructure or other programs which have been approved by the People Representatives Council in a discussion of the State Budget Proposal, or specifically it has been approved by the People Representatives Council. 
According to the previous explanation, the Constitutional Court assesses that since the purchase of the divestment above using the fund from the Government Investment Center can potentially causes loss for the state that could have a negative impact on the national economy, the purchase of the divestment needs to ask for approval from the People Representatives Council as stated in the consideration:

"...The use of fund from the Government Investment Center without the approval of the Respondent I can potentially causes loss that could have a negative impact on the national economy and potentially leads to a misuse of fund if the accumulation of fund from the Government Investment Center which the amount is getting bigger, is used by the President c.q the Minister of Finance without involving the Respondent I. On the other hand, the Respondent I is authorized to do a supervision. The case will be different if the Government Investment Center is a state company whose wealth is separated from the state's wealth. In a case of A quo, the Court cannot find any convincing evidence that the purchase of $7 \%$ shares of PT. Newmont Nusa Tenggara has been discussed and approved by the Respondent I in a Law of State Budget Plan (UU RAPBN) since in fact in the constitution itself, the State Budget does not mention the investment specifically."

The further legal consideration toward the primary case, the Constitutional Court states:

"The Court assessed that the purchase of $7 \%$ of divestment shares of PT Newmont Nusa Tenggara is the constitutional authority of the Petitioner in running the state which can only be done by: (i) the approval of the Respondent I, both through the Law of State Budget (UU APBN) or specifically approved by the Respondent I; (ii) it is implemented openly and responsibly for the welfare of the nation; and (iii) it is implemented under the supervision of the Respondent I. Since the purchase of $7 \%$ shares of PT Newmont Nusa Tenggara specifically has not been included in the State Budget and also has not gotten any approval from the People Representatives Counsil, the petition does not have a legal standing."

Therefore, the Constitutional Court assessed that in purchasing $7 \%$ shares of PT Newmont Nusa Tenggara planned by the President, an approval from the People Representatives Counsil is still needed. Based on the explanation, it can be concluded that the refusal of the Constitutional Court toward 
the petition of the dispute about authority of state institutions filed by the President is not the subjectum litis and objectum litis of the case of a quo which have not been fulfilled, but because the Constitutional Court assessed the absence of constitutional problem on the Petition.

\section{CONCLUSIONS}

To determine the subjectum litis of a dispute about state institutions, thoroughness is needed since there are institutions whose names are explicitly mentioned in the provision and some others are only mentioned by its function. There are institutions or organs whose name, function, or the authority which will be governed by a lower level regulation. An authority which is not clearly mentioned in a constitution but it is necessary to run its constitutional authority given explicitly is an authority which is given by the constitution, although it is then clearly explained in a law as the implementation of the 1945 Constitution. The regulation of a material of an authority does not automatically make it become a non-constitutional authority. On the other hand, if an authority is mentioned in a law, it does not mean that the law becomes the source of that authority. The problem is whether that authority is inherent or not, and the authority needs to be realized as it is clearly assigned by the constitution.

From several verdicts of the Constitutional Court above, it can be concluded, first, the Court can assess the subjectum litis and objectum litis of a dispute about authority of state institutions by using the Article 61 of Law of the Constitutional Court which covers the following points:

(1) The petitioner is state institutions whose authority is given by the 1945 Constitution of the State of the Republic of Indonesia which has direct interest toward the disputed authority.

(2) The petitioner needs to clearly elaborate the petition related to its direct interest, elaborate the disputed authority, and clearly elaborate the state institutions who become the respondent.

Based on the Article 61 of Law of the Constitutional Court mentioned above, it can be concluded as follow:

a) Both the petitioner and the respondent are state institutions whose authorities are given by the 1945 constitution; 
b) There is a disputed constitutional authority filed by the petitioner and the respondent, where the constitutional's authority of the petitioner is taken over and/or intervented by the respondent;

c) The petitioner needs to have direct interest toward the disputed constitutional authority.

Therefore, the authority of the court and the legal standing of the petitioner cannot be separated. The incomplete one of the three cumulative requirements above in a petition makes the court does not have any authority to conduct a hearing of a petition. The second, in relation to the assessment of subjectum litis in a formal juridical manner, the Constitutional Court is authorized to resolve the dispute about authority of state institutions given by the 1945 constitution

\section{References}

Ekatjahjana, Widodo, and Totok Sudaryanto. Sumber Hukum Tata Negara Formal Di Indonesia. Bandung: Citra Aditya Bhakti, 2001.

Fadjar, Abdul Mukthie. Hukum Konstitusi Dan Mahkamah Konstitusi. Jakarta: Sekretariat Jenderal dan Kepaniteraan Mahkamah Konstitusi, 2006.

Firmansyah, Arifin. Lembaga Negara Dan Sengketa Kewenangan Antarlembaga Negara. Jakarta: Konsorsium Reformasi Hukum Nasional (KRHN), 2005.

Hakim, Lukman. "Konsorsium Reformasi Hukum Nasional (KRHN)." Yustisia Jurnal Hukum 8o (2010).

Judicial Review on Dispute over the authority of State Institutions whose authorities are granted by the 1945 Constitution of the State of the Republic of Indonesia, filed by Drs. Aziz Kharie, ME (as the Chairman of the General Election Commissions of North Maluku and as the mandate holder of the General Election Commissions) against the President of the Republic of Indonesia (as the Respondent), No. 27/SKLN-VI/2008 (The Constitutional Court of the Republic of Indonesia 2008).

Judicial Review on Dispute over the authority of State Institutions whose authorities are granted by the 1945 Constitution of the State of the Republic of Indonesia, filed by Drs. H. M. Saleh Manaf (the Regent of Bekasi) and Drs. Solihin Sari (Vice Regent of Bekasi) againts the President of the Republic of Indonesia (Respondent I), Ministry of Home Affairs of the Republic of Indonesia (Respondent II), and the Regional People Representatives Council of Bekasi Regency (Respondent III), No. 004/SKLN-IV/2006 (The Constitutional Court of the Republic of Indonesia 2006). 
Judicial Review on Dispute over the authority of State Institutions whose authorities are granted by the 1945 Constitution of the State of the Republic of Indonesia, filed by H. Andi Harahap, S.Sos (as the Regent of North Penajam Paser) and Nanang Ali, S.E (as the head of the Regional People Representatives Council of North Penajam Paser Regency) against the Minister of Environment and Forestry of the Republic of Indonesia as the Respondent, No. 2/SKLN-IX/2011 (The Constitutional Court of the Republic of Indonesia 2011).

Judicial Review on Dispute over the authority of State Institutions whose authorities are granted by the 1945 Constitution of the State of the Republic of Indonesia, filed by Indonesian Broadcasting Commission (as a Petitioner) against the President of the Republic of Indonesia q.q. the Minister of Communications and Informatics (as the Respondent), No. 030/SKLN-IV/2006 (The Constitutional Court of the Republic of Indonesia 2006).

Judicial Review on Dispute over the authority of State Institutions whose authorities are granted by the 1945 Constitution of the State of the Republic of Indonesia, filed by Ir.H. Abdullah Tuasikal, M.Si (as the Regent of Central Maluku) and Asis Mahulette, S.H (as the head of the Regional People Representatives Council of Central Maluku Regency) against the Respondent, the Minister of Home Affairs of the Republic of Indonesia., No. 1/SKLNVIII/2010 (The Constitutional Court of the Republic of Indonesia 2010).

Judicial Review on Dispute over the authority of State Institutions whose authorities are granted by the 1945 Constitution of the State of the Republic of Indonesia, filed by the Independent Election Commission of Southeast Aceh Regency level (Petitioner I) and the Regional People Representatives Council (Petitioner II) against the Independent Election Commission of Nanggroe Aceh Darussalam Province level (Respondent I), the Governor of Nanggroe Aceh Darussalam (Respondent II), and the President of Republic of Indonesia c.q the Minister of Home Affairs of the Republic of Indonesia (Respondent III)., No. 26/SKLN-V/2007 (The Constitutional Court of the Republic of Indonesia 2007).

Judicial Review on Dispute over the authority of State Institutions whose authorities are granted by the 1945 Constitution of the State of the Republic of Indonesia, filed by the President against the Respondent, the People Representatives Council and the Audit Board of the Republic of Indonesia, No. 2/SKLN-X/2012 (The Constitutional Court of the Republic of Indonesia 2012).

Judicial Review on Dispute over the authority of State Institutions whose authorities are granted by the 1945 Constitution of the State of the Republic of Indonesia, filed by the Working Committee of Indonesian Advocate 
(KKAI) against the Supreme Court of Indonesia as the Respondent., No. 5/ SKLN-IX/2011 (The Constitutional Court of the Republic of Indonesia 2011).

Latif, Abdul. Fungsi Mahkamah Konstitusi Dalam Upaya Mewujudkan Negara Hukum Demokrasi. Yogyakarta: Kreasi Total Media, 2007.

Mahkamah Konstitusi Republik Indonesia. "Hukum Acara Mahkamah Konstitusi." Sekretaris Jenderal dan Kepaniteraan Mahkamah Konstitusi, 2010.

Siahaan, Maruarar. Hukum Acara Mahkamah Konstitusi Republik Indonesia. Jakarta: Sekretariat Jenderal dan Kepaniteraan Mahkamah Konstitusi, 2006.

——_. "Sengketa Kewenangan Antarlembaga Negara." Jakarta, 2008.

The 1945 Constitution of the Republic of Indonesia (1945).

The Constitutional Court of the Republic of Indonesia. Constitutional Court Regulation (n.d.). 